\title{
GERMINATION ECOLOGY OF Rhynchosia capitata: AN EMERGING SUMMER WEed IN ASIA ${ }^{1}$
}

\author{
Ecologia da Germinação de Rhynchosia capitata: Planta Daninha Emergente Durante o Verão \\ na Ásia
}

\begin{abstract}
ALI, H.H. ${ }^{{ }^{2}}$, TANVEER, A. ${ }^{2}$, NADEEM, M.A. ${ }^{2}$, ASGHAR, H.N. ${ }^{3}$, and JAVAID, M.M. ${ }^{4}$
ABSTRACT - Rhynchosia capitata is becoming an increasing problem in summer crops, such as cotton, soybean, pearl millet and mungbean in many Asian countries. Laboratory and greenhouse studies have been conducted to determine the effects of several environmental factors on seed germination patterns and seedling emergence of $R$. capitata. We investigated whether the diverse ecological factors such as temperature, light, salinity, moisture stress, $\mathrm{pH}$, and soil depth affected germination and seedling emergence of $R$. capitata. Germination increased as temperature increased from $25^{\circ} \mathrm{C}$ and significantly reduced at $45^{\circ} \mathrm{C}$. Presence or absence of light did not influence germination. Germination of $R$. capitata was sensitive to increased salt and moisture stress, as well as to seed burial depth. Only $48 \%$ of seeds germinated at $150 \mathrm{mM}$ salt concentration compared to $100 \%$ in control (distilled water). Similarly, $15 \%$ of seeds germinated at an osmotic potential of $-0.8 \mathrm{MPa}$ compared to $88 \%$ at $-0.2 \mathrm{MPa}$. The optimum $\mathrm{pH}$ for seed germination of $R$. capitata was 7 (98\% germination), but the seeds also germinated at lower level of $\mathrm{pH} 5(85 \%)$ and at higher level of $\mathrm{pH} 10(75 \%)$. In seed burial trial, maximum seedling emergence of $93 \%$ occurred at $2 \mathrm{~cm}$ depth, and seedling did not emerge from a depth of $12 \mathrm{~cm}$. The high germination ability of $R$. capitata under a wide range of ecological factors suggests that this species is likely to be the one to cause more problems in a near future, if not managed appropriately.
\end{abstract}

Keywords: moisture stress, $\mathrm{pH}$, salinity, seedling emergence, burial depth.

RESUMO - A Rhynchosia capitata vem se tornando um problema crescente para culturas de verão como algodão, soja, milheto e feijão-mungo em muitos países asiáticos. Foram feitos estudos de laboratório e estufa para determinar os efeitos de vários fatores ambientais sobre os padrões de germinação das sementes e emergência das plântulas de $\boldsymbol{R}$. capitata. Diversos fatores ecológicos, tais como, temperatura, luz, salinidade, estresse hídrico, $\mathrm{pH}$ e profundidade do solo foram avaliados para saber se afetam a germinação e emergência das plântulas de $\boldsymbol{R}$. capitata. A germinação aumentou à medida que a temperatura aumentou a partir de $25^{\circ} \mathrm{C}$ e reduziu significativamente a $45^{\circ} \mathrm{C}$. $\mathrm{A}$ presença ou ausência de luz não influenciou a germinação. A germinação das sementes de $\boldsymbol{R}$. capitata se mostrou sensivel ao aumento dos estresses hídrico e salino, bem como à profundidade do enterrio das sementes. Apenas 48\% das sementes germinaram a 150 mMde concentração salina, em comparação com 100\% no controle (água destilada). Do mesmo modo, 15\% das sementes germinaram a um potencial osmótico de -0, 8 MPa, em comparação com 88\% a-0,2 MPa. OpHideal para a germinação de sementes de R. capitata foi 7 (98\% de germinação), mas as sementes germinaram também a um nivel inferior de pH 5 (85\%) e superior de pH 10 (75\%). No experimento de enterrio das sementes, a máxima emergência das plântulas de 93\% foi a $2 \mathrm{~cm}$ de profundidade e as plântulas não emergiram a partir da profundidade de $12 \mathrm{~cm}$. A alta capacidade de germinação da $\boldsymbol{R}$. capitata sob uma ampla gama de fatores ecológicos sugere que provavelmente esta espécie será a que mais causará problemas em um futuro próximo se não for gerida de forma adequada.

Palavras-chave: estresse hídrico, $\mathrm{pH}$, salinidade, emergência de plântulas, profundidade de enterrio.

Recebido para publicação em 8.7.2012 e aprovado em 8.10.2012

2 Department of Agronomy, University of Agriculture Faisalabad, 38040, Pakistan, : < haider3993@gmail.com>; ${ }^{3}$ Institute of Soil and Environmental Sciences, University of Agriculture Faisalabad, 38040, Pakistan; ${ }^{4}$ Department of Agronomy, University College of Agriculture, University of Sargodha, 40100, Pakistan. 


\section{INTRODUCTION}

The genus Rhynchosia of family Fabaceae is widely distributed in the mountainous regions of the tropics. Rhynchosia capitata, an emerging annual summer weed, is indigenous to Pakistan (Jahan et al., 1994), India (Dogra et al., 2009), and Sri Lanka (Ildis, 2010). It has invaded the cultivated areas of Southern Punjab of Pakistan and is increasingly becoming a problematic weed in farming systems (Ali et al., 2011). Among the various factors that cause low yield in Pakistan, weeds play a major role. Yield losses due to uncontrolled weed growth in mungbean range from 35 to 69\% (Yadav \& Sing 2005; Raman \& Krishnamoorthy, 2005), in cotton from 15 to $40 \%$ (Khan \& Khan 2003) and in soybean from 58 to $85 \%$ depending on the type and weed intensity of infestation (Kolhe et al., 1998).

In the field, weeds emerge from the seed just after irrigation. It is an annual twinning prostrate plant with many branches spreading all around the rootstock and rooting at every node. Approximately one month old plants start flowering and oval-shaped pods appear with two seeds in each pod (Sharma et al., 1978). Seeds usually require scarification to germinate. Seed dormancy is the major motive of the success of this species, since it allows the seeds of this species to remain for long periods in the soil and thus escape the effects of post-emergence weed control measures. The growing season happens from May to October with minimum and maximum mean temperatures of $29 / 21 \pm 3{ }^{\circ} \mathrm{C}$ and $39 / 29 \pm 3{ }^{\circ} \mathrm{C}$, respectively, and average rainfall of $650 \mathrm{~mm}$ (Ali et al., 2011).

One of the major objectives of seed germination ecology is to assess how the timing of germination occurs in nature. Research on seed germination ecology helps to recognize and explain plant evolution and ecological adaptation (Baskin et al., 2004). Seed germination is a susceptible stage in plant life cycle and seedlings are frequently exposed to variable environmental conditions. Consequently, for weed management, all possibilities of mortality at the stage of seedling emergence should be considered (Chauhan \& Johnson, 2009). Only a thorough understanding of weed ecology can bring about further improvements in current weed management practices. The extensive literature on seed germination illustrates that germination is influenced by several environmental factors including light, temperature, moisture and burial depth through tillage (Benech-Arnold et al., 2000).

Since there is no information about $R$. capitata, we should consider some insights on related species of the family Fabaceae. Temperature is the primary factor governing seed germination. Many weed species have the ability to germinate under a wide range of temperature levels. A range of alternating temperatures has little influence on the germination of giant sensitive plant (Mimosa invisa) seeds (Chauhan \& Johnson, 2008). In the distribution of weed seeds at various soil depths, the germination response of seeds may vary according to different soil temperatures and moisture contents (Chauhan et al. 2010). In many weed species like Mimosa pudica, absence of light had no effect on seed germination (Chauhan \& Johnson, 2009a).

Salinity is a considerable problem in most of the irrigated lands of Punjab, Pakistan (Azhar \& Tariq, 2003). Salts can also affect seed germination either by limiting water availability or by causing specific injury through ions to the metabolic mechanism. Seeds of $M$. invisa have the ability to germinate when exposed to a wide range of saline conditions (Chauhan \& Johnson, 2008). However, germination of Lotus creticus was significantly delayed and reduced with increased $\mathrm{NaCl}$ to levels above $300 \mathrm{mM}$ (Rejili et al., 2009). Another factor that may negatively affect seed germination is moisture stress (Wilson et al., 1985). Seeds exposed to unfavorable environmental conditions, like water stress, have poor seedlings establishment (Albuquerque \& Carvalho, 2003).

Awareness about emergence patterns of weed seedlings at different soil depths is important for the successful employment of many weed management strategies (Leon \& Owen, 2006). The placement of weed seeds in the soil plays a significant role in seedling emergence and seed survival (Reuss et al., 2001). Burial of weed seeds to variable depths may not only influence total seedling 
recruitment from the soil, it could also affect the vigor of the seedlings that establish (Cousens \& Moss, 1990). Weed seed mortality in and on soil vary according to weed species, seed burial depth and soil disturbances (Mohler, 2001).

Many weed seeds can germinate over a broad range of $\mathrm{pH}$ (Chauhan \& Johnson, 2008). Lefevre (1956) reviewed the $\mathrm{pH}$ tolerance of 60 weeds and grouped them into basophile (love basic soils), e.g., sow thistles (Sonchus oleraceus), green sorrel (Rumex acetosa), quack grass (Elymus repens), and dandelion (Taraxacum officinale); acidophile (love acid soil), e.g., red sorrel (Rumex cetosella), corn marigold (Chrysanthemum segetum), and neutrophile. Generally, the seeds of family Fabaceae are sensitive to acidity (Brkic et al., 2004).

Nothing is known about the germination ecology of $R$. capitata, making this type of weed more difficult to manage. Therefore, the specific objective of this study was to determine the effects of temperature, light, salt stress, osmotic stress, seeding depth, and $\mathrm{pH}$ on $R$. capitata seed germination and seedling emergence.

\section{MATERIALS AND METHODS}

\section{Seed collection}

Mature pods of $R$. capitata were collected from more than 500 plants from mungbean fields around Layyah, Southern Punjab, Pakistan (30 57' N, 70 56' E) in October 2010. Immediately after collection, seeds were isolated from the pods, separated from the undesired materials and unripe seeds, placed in plastic containers, and stored at room temperature $\left(25 \pm 1.4{ }^{\circ} \mathrm{C}\right)$ before used in the experiments. Only mature and uniform-sized seeds were used for various seed germination experiments.

\section{Germination test}

The seeds were surface sterilized by soaking in $5 \%$ sodium hypochlorite $(\mathrm{NaOCl})$ solution for $5 \mathrm{~min}$ and subsequently rinsed thoroughly with sterilized water. After rinsing, the seeds were left to dry out on the blotter paper at laboratory temperature $\left(25 \pm 1.4{ }^{\circ} \mathrm{C}\right)$. Seed germination was estimated by placing 25 seeds evenly in a $9 \mathrm{~cm}$ diameter Petri dish containing two layers of Whatman No. 1 filter paper, moistened with $5 \mathrm{~mL}$ distilled water or a treatment solution. Seeds of $R$. capitata had high levels of innate dormancy and were scarified by sand paper (the seed coat was sanded with a \# 80 wood sandpaper at an area opposite from the embryo until the cotyledon was exposed) before applying any treatment (Ali et al., 2011). Scarified seeds were used in all experiments. All dishes were sealed with a strip of parafilm to reduce water loss and placed in a germinator at $30{ }^{\circ} \mathrm{C}$. Germination counts were made every day for $4 \mathrm{wk}$. A seed was considered to have germinated when the tip of the radicle $(2 \mathrm{~mm})$ had grown out of the seed.

\section{Experiment 1: effect of temperature on the germination of $R$. capitata}

To know whether seeds of $R$. capitata have the ability to germinate under various temperatures, as seed might experience a wide range of temperature conditions in southern Punjab of Pakistan, seeds were placed in germinators at various temperatures $(20$, $25,30,35,40$ and $45{ }^{\circ} \mathrm{C}$ ) to determine optimum temperature for germination.

\section{Experiment 2: effect of light and darkness on the germination of $R$. capitata}

The influence of light on the germination of $R$. capitata seeds was assessed. Scarified seeds were placed evenly at Whatman No. 10 filter paper in $9 \mathrm{~cm}$ diameter Petri dish wrapped in two layers of aluminum foil to ensure no light penetration (dark), or left uncovered to allow light exposure (light/dark) and placed in a germinator at $30{ }^{\circ} \mathrm{C}$.

\section{Experiment 3: effect of different levels of salt stress on the germination of $R$. capitata}

To assess germination ability of $R$. capitata under different levels of salt stress, scarified seeds of $R$. capitata were placed evenly at Whatman No. 10 filter paper in $9 \mathrm{~cm}$ diameter Petri dish. $\mathrm{NaCl}$ solutions $(5 \mathrm{~mL})$ of $0,50,100$, 150, 200 and $250 \mathrm{mM}$ concentrations were 
given to each Petri dish separately and were sealed with a strip of parafilm to prevent moisture loss. Afterwards, Petri Dishes were placed in a germinator at $30^{\circ} \mathrm{C}$.

\section{Experiment 4: effect of different levels of osmotic potential on the germination of R. capitata}

The germination response of $R$. capitata under different levels of moisture stress was assessed under laboratory conditions. Polyethylene glycol with a molecular weight of 8000 (PEG-8000) was used as a drought stimulator and water stress levels of zero (control), -0.2, -0.4, -0.6, -0.8 and - 1.0 MPa were developed according to the equation proposed by Michel (1983). The selected ranges of osmotic potentials simulate water stress levels that occur in most farming systems of Punjab, Pakistan during the summer.

\section{Experiment 5: effect of different levels of pH on the germination of $R$. capitata}

The effect of $\mathrm{pH}$ on the germination of $R$. capitata was studied using buffer solutions of $\mathrm{pH} 5$ to 10 prepared as described by Reddy $\&$ Singh (1992) to simulate the $\mathrm{pH}$ ranges of Pakistani soils. A $2-\mathrm{mM}$ solution of MES [2-( $N$-morpholino) ethanesulfonic acid] was adjusted to $\mathrm{pH} 5$ or 6 with $1 \mathrm{~N} \mathrm{NaOH}$. A 2-mM solution of HEPES [ $N$-(2-hydroxymethyl) piperazine- $N$-(2-ethanesulfonic acid)] was adjusted to $\mathrm{pH} 7$ or 8 with $1 \mathrm{~N} \mathrm{NaOH}$. A pH 9 or 10 buffer was prepared with $2-\mathrm{mM}$ tricine [ $N$-tris (hydroxymethyl) methylglycine] and adjusted with $1 \mathrm{~N} \mathrm{NaOH}$. Unbuffered deionized water (pH 6.3) was used as a control.

\section{Experiment 6: effect of different levels of sowing depth on the seedling emergence of $R$. capitata}

To study the effect of different levels of sowing depth on the seedling emergence of $R$. capitata, 50 scarified $R$. capitata seeds were placed on the soil surface in 14-cm-diam plastic pots and then covered with soil to achieve burial depths of $0,2,4,6,8,10$ and $12 \mathrm{~cm}$. The sandy loam soil was used for this experiment with $0.7 \%$ organic carbon and a $\mathrm{pH}$ of 7.5. Control pots, where seeds were not added, indicated that there was no background seed bank of $R$. capitata in the study soil. Soil was sieved in a $3 \mathrm{~mm}$ sieve. Pots were watered as needed to maintain adequate soil moisture. Emergence was counted daily and the experiment was carried out $40 \mathrm{~d}$ after burial. The temperature of the glasshouse ranged from 32.6 to $\pm 3.7{ }^{\circ} \mathrm{C}$ during the day and from 23.8 to \pm 3.2 during the night.

\section{Statistical analysis}

Each experiment had a completely randomized design (CRD) with four replications. All experiments were repeated. The data from the repeated experiments were combined because there was no time-by-treatment interaction. The germination index (GI) was calculated as described by the Association of Official Seed Analysts (AOSA, 1990) by using the following formula:

GI $=\frac{\text { No. of germinated seeds }}{\text { Days of first count }}+------+\frac{\text { No. of germinated seeds }}{\text { Days of final count }}$

Time taken to $50 \%$ germination of seedlings $\left(\mathrm{T}_{50}\right)$ was calculated according to the following formulae of Coolbear et al. (1984),

$$
T_{50}=t_{i}+\frac{\left(N / 2-n_{i}\right)\left(t_{j}-t_{i}\right)}{n_{j}-n_{i}}
$$

where $N$ is the final number of germinated seeds, and $n_{i}$ and $n_{j}$ are the cumulative number of seeds germinated by adjacent counts at times $t_{i}$ and $t_{j}$, respectively, when $n_{i}<N / 2<n_{j}$

Mean germination time (MGT) was calculated according to the equation of Ellis \& Roberts (1981):

$$
M G T=\Sigma\left(D_{n}\right) / \Sigma n
$$

where $n$ is the number of germinated seeds or emerged seedlings on day $D$ and $D$ is the total number of days counted from the beginning of germination.

Germination (\%) values at different concentrations of $\mathrm{NaCl}$, osmotic potential as well as emergence (\%) of the seeds buried at different depths were fitted to a functional three-parameter logistic model (Chauhan et al., 2006) using Sigma Plot 2008 (version 11.0). The fitted model was 


$$
\left.\left\{G(\%)=G_{\max } /\left[1+\left(x / x_{50}\right) G_{\text {rate }}\right]\right\} \quad \text { (eq. } 1\right)
$$

where $G$ is the total germination (\%) at concentration $x, G_{\max }$ is the maximum germination $(\%), x_{50}$ is the $\mathrm{NaCl}$ concentration or osmotic potential for $50 \%$ inhibition of the maximum germination and $G_{\text {rate }}$ indicates the slope. Similarly, in case of seedling emergence, the model fitted was $\left\{E(\%)=E_{\max }\right.$ $\left./\left[1+(x / x 50) E_{\text {rate }}\right]\right\}$ where $\mathrm{E}$ is the total seedling emergence (\%) at depth $x, E_{\max }$ is the maximum seedling emergence and $E_{\text {rate }}$ indicates the slope. In all other experiments, means were separated using LSD at $\mathrm{P}=0.05$.

Data were analyzed statistically by Fisher's ANOVA function of the MSTAT statistical computer package, and LSD at $5 \%$ probability was used to compare treatment means (Steel et al., 1997).

\section{RESULTS AND DISCUSSION}

\section{Temperature and light}

Rhynchosia capitata seed germination was significantly higher $(97.5 \%)$ at $30{ }^{\circ} \mathrm{C}$ followed by $82.5 \%$ at $35{ }^{\circ} \mathrm{C}$ (Table 1$)$. The lowest germination $(17.5 \%)$ was recorded at $45{ }^{\circ} \mathrm{C}$. Rhynchosia capitata seeds took minimum time (0.83 days) to complete $50 \%$ germination at $25{ }^{\circ} \mathrm{C}$, which was statistically at par with $30^{\circ} \mathrm{C}$ and $20{ }^{\circ} \mathrm{C}$ in which the seeds took 0.89 days and 0.91 days to complete $50 \%$ germination, respectively. Germination index (GI) was significantly high $(7.12)$ at $30{ }^{\circ} \mathrm{C}$ followed by 5.71 and 5.70 at $25^{\circ} \mathrm{C}$ and $35^{\circ} \mathrm{C}$, respectively. Minimum MGT (2.16 days) was observed at $25{ }^{\circ} \mathrm{C}$ while the seeds took maximum MGT (2.87 days) at $45^{\circ} \mathrm{C}$.

The response of $R$. capitata to a range of temperatures is similar to that reported for other weed species, such as giant sensitive plant (M. invisa) (Chauhan \& Johnson, 2008). Rhynchosia capitata germinates under a broad range of temperatures and other environmental conditions, for instance, it is able to germinate in dense shaded areas, such as under a crop canopy. The optimum temperatures for $R$. capitata germination are similar to those of summer temperatures in southern Punjab, Pakistan. Temperature below a constant temperature of $25{ }^{\circ} \mathrm{C}$ was not favourable for
Table 1 - Effect of different temperatures on the germination of R. capitata

\begin{tabular}{|c|c|c|c|c|}
\hline Treatment & $\begin{array}{c}\text { Germination } \\
(\%)\end{array}$ & $\begin{array}{c}\mathrm{T}_{50} \\
(\text { days })\end{array}$ & $\begin{array}{c}\text { MGT } \\
(\text { days })\end{array}$ & GI \\
\hline Temperature $\left({ }^{\circ} \mathrm{C}\right)$ & & & & \\
\hline 45 & $17.5 \mathrm{e}$ & $2.76 \mathrm{a}$ & $2.87 \mathrm{a}$ & $0.66 \mathrm{~d}$ \\
\hline 40 & $65.0 \mathrm{c}$ & $1.35 \mathrm{~b}$ & $2.32 \mathrm{~b}$ & $4.04 \mathrm{c}$ \\
\hline 35 & $82.5 \mathrm{~b}$ & $1.46 \mathrm{~b}$ & $2.24 \mathrm{bc}$ & $5.71 \mathrm{~b}$ \\
\hline 30 & $97.5 \mathrm{a}$ & $0.89 \mathrm{c}$ & $2.19 \mathrm{bc}$ & $7.12 \mathrm{a}$ \\
\hline 25 & $75.0 \mathrm{~b}$ & $0.83 \mathrm{c}$ & $2.16 \mathrm{c}$ & $5.70 \mathrm{~b}$ \\
\hline 20 & $55.0 \mathrm{~d}$ & $0.91 \mathrm{c}$ & $2.19 \mathrm{bc}$ & $4.04 \mathrm{c}$ \\
\hline LSD $(0.05)$ & 8.0230 & 0.1150 & 0.1557 & 0.7082 \\
\hline
\end{tabular}

Means followed by the same letter in a column did not differ significantly according to LSD test $(\mathrm{p}<0.05) . \mathrm{T}_{50}$ : Time needed for $50 \%$ germination; MGT: Mean germination time; GI: Germination index; LSD: Least significance difference.

germination; as a result, the spreading of this weed may be limited to the warmer temperatures of summer in these regions. Similar results may be found in soil under field conditions at these temperatures, because this weed starts to germinate soon after irrigation or rainfall.

Rhynchosia capitata seeds germinated in both light and dark conditions. The response of $R$. capitata to light and dark was similar to that observed by Chauhan \& Johnson (2008) in giant sensitive plant ( $M$. invisa) in which seed germinated similarly in the presence of light and in the dark. Seeds of $R$. capitata are able to germinate in complete darkness; this could explain why germination occurs from deep depths in soils, under plant canopy and litter shade.

\section{Salt stress}

A three-parameter logistic model $\{G(\%)$ $\left.=94.6 /\left[1+(x / 137.6)^{6.2}\right], \mathbf{R}^{2}=0.96\right\}$ was fitted to the germination data found at different concentrations of $\mathrm{NaCl}$ (Figure 1). Data suggest that $R$. capitata seed germinated even at high salinity levels. Germination was greater than $90 \%$ at $0 \mathrm{mM} \mathrm{NaCl}$ and some germination (10\%) occurred even at $200 \mathrm{mM} \mathrm{NaCl}$. Germination was completely inhibited at $250 \mathrm{mM} \mathrm{NaCl}$. The concentration for $50 \%$ inhibition of the maximum germination, estimated from the fitted model (Equation 1), was $137.6 \mathrm{mM} \mathrm{NaCl}$. 


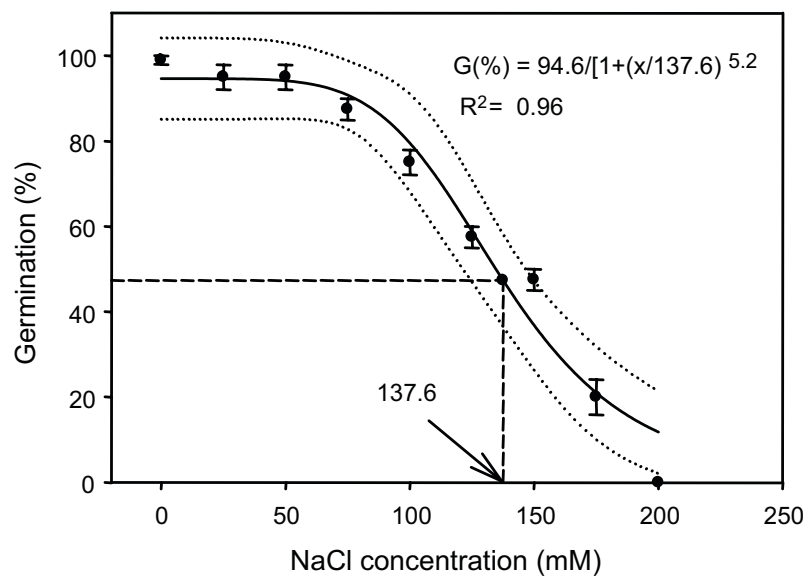

Figure 1 - Effect of sodium chloride $(\mathrm{NaCl})$ concentration on the germination of $R$. capitata. Line represents the functional three-parameter logistic model $\left\{G(\%)=G_{\max } /[1+(x /\right.$

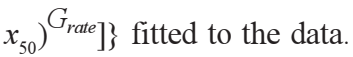

Results show that $R$. capitata seeds are able to germinate even at high soil salinity and such soil types are common in many parts of Punjab, Pakistan (Azhar \& Tariq, 2003). Similar results were found by Chauhan et al. (2006) in annual sowthistle (Sonchus oleraceus) in which more than $90 \%$ of seeds germinated at a low level of salinity $(40 \mathrm{mM} \mathrm{NaCl})$ and some seeds $(7.5 \%)$ germinated even at $160 \mathrm{mM}$ $\mathrm{NaCl}$.

It is a well-known fact that salinity affects seed germination adversely due to disturbances in physiological and metabolic processes occurring in a plant body (Afzal et al. 2006). Response of $R$. capitata to salinity may be due to its affect on seed germination by generating an external osmotic potential that avoids water uptake or due to the toxic effects of $\mathrm{Na}^{+}$and $\mathrm{Cl}^{-}$ions on the germinating seed, which has also been reported by KhajehHosseini et al. (2003). In other words, $R$. capitata was found comparatively more tolerant to salinity, as it had 7.5 percent germination at $200 \mathrm{mM}$ of $\mathrm{NaCl}$ concentration compared to its control treatment against higher salinity levels.

\section{Osmotic stress}

A three-parameter logistic model $\{G(\%)=$ $\left.94.8 /[1+(x /-0.8)], \mathrm{R}^{2}=0.98\right\}$ was fitted to the germination values $(\%)$ found at different osmotic potential (Figure 2). Germination decreased from 100 to $15 \%$ as osmotic potential increased from 0 to $-0.6 \mathrm{MPa}$. Germination was completely inhibited at osmotic potential of $-1.0 \mathrm{MPa}$. However, more than $10 \%$ germination at an osmotic potential of $-0.6 \mathrm{MPa}$ indicates that some seeds of $R$. capitata can germinate under marginal water-stress conditions. The osmotic potential for $50 \%$ inhibition of the maximum germination, estimated from the fitted model (Equation 1), was $-0.48 \mathrm{MPa}$.

Results suggest that $R$. capitata is a weed favoured by a moist environment that may occur in field conditions just after rainfall or irrigation. Lowest germination $(15 \%)$ at an osmotic potential of $-0.8 \mathrm{MPa}$ indicates that $R$. capitata can germinate under moderate water stress conditions, which are typical during the summer in the dry region of Punjab. Likewise, germination of annual sowthistle (Sonchus oleraceus) also decreased from $95 \%$ to $11 \%$ as osmotic potential increased from 0 to $-0.6 \mathrm{MPa}$ and was completely inhibited at osmotic potential greater than $0.6 \mathrm{MPa}$ (Chauhan et al., 2006). In contrast to $R$. capitata, trumpet creeper (Campsis radicans) (Chachalis \& Reddy, 2000) was highly sensitive to low osmotic potential. Germination of $R$. capitata over this range of osmotic potential indicates that this weed could pose a weed threat under low and high soil moisture conditions.

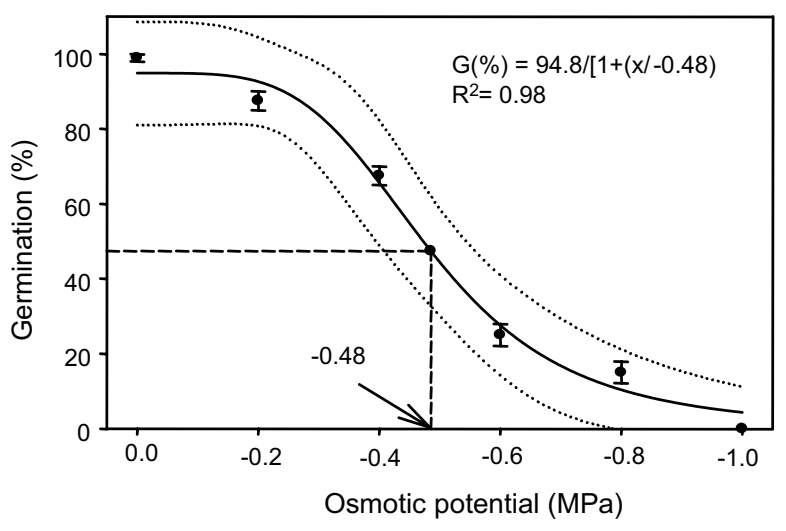

Figure 2 - Effect of osmotic potential on the germination of $R$. capiata seeds. Line represents the functional three-parameter logistic model $\left\{G(\%)=G_{\max } /\left[1+\left(x / x_{50}\right)^{G_{\text {rate }}}\right]\right\}$ fitted to the data. 
pH

Seeds of $R$. capitata were able to germinate over a wide range of $\mathrm{pH}$ (5-10). Seed germination was less affected with increased rate of $\mathrm{pH}$ from 6 to 8 and then reduced at higher $\mathrm{pH}$ levels (Table 2). Maximum germination $(97.5 \%)$ was recorded at $\mathrm{pH} 7$, followed by $95 \%$ and $92.5 \%$ at $\mathrm{pH}$ level of 8 and 6 , respectively, but these were statistically at par with one another. Seed germination was $85 \%$ and $75 \%$ at pH 5 and 10 , respectively. However, at $\mathrm{pH}$ level of 10 , time to $50 \%$ germination (1.66 days) and MGT (2.97 days) was at maximum as compared to other $\mathrm{pH}$ levels.

In Pakistan, soils are mostly developed from calcareous alluvial and loessial deposits, so most of the soils have alkaline $\mathrm{pH}$ and low organic matter $(\mathrm{OM})$ contents under canal and tube well irrigated areas of Punjab (Niaz et al., 2007). Therefore, germination and survival of $R$. capitata over a broad range of $\mathrm{pH}$ indicates that $\mathrm{pH}$ may not be a limiting factor for germination in most soil conditions of Pakistan. These results are similar to those reported for seeds of giant sensitive plant $(M$. invisa) which germinated best from $\mathrm{pH} 4$ to 10 (Chauhan \& Johnson, 2008.). Our data suggest that this species may harm summer crops and pastures throughout Punjab, where soil $\mathrm{pH}$ can widely vary.

\section{Burial depth}

Rhynchosia capitata seedling emergence data were also fitted to three-parameter logistic model $\left\{E(\%)=88.08 /\left[1+(x / 7.74)^{8.4}\right]\right\}$, $\mathrm{R}^{2}=0.99$; where $E$ represents seedling emergence $(\%)$ and $x$ represents depth $(\mathrm{cm})$ of seed burial]. Seedling emergence of $R$. capitata decreased with increased planting depth (Figure 3). Seedling emergence was greater than $80 \%$ for seeds placed on the soil surface and no seedlings emerged from seeds placed at a depth of $12 \mathrm{~cm}$. The emergence of seedlings at deeper soil layers $(10 \mathrm{~cm})$ showed that light is not a limiting factor for the germination of $R$. capitata.

When seeds buried at 10 and $12 \mathrm{~cm}$ depths were examined, it was found that most of the seeds at $10 \mathrm{~cm}$ depth and all seeds at
Table 2 - Effect of different levels of $\mathrm{pH}$ on the germination of R. capitata

\begin{tabular}{|c|c|c|c|c|}
\hline Treatment & $\begin{array}{c}\text { Germination } \\
(\%)\end{array}$ & $\begin{array}{c}\mathrm{T}_{50} \\
(\text { days })\end{array}$ & $\begin{array}{c}\text { MGT } \\
(\text { days })\end{array}$ & GI \\
\hline $\mathrm{pH}$ & & & & \\
\hline 5.0 & $85.0 \mathrm{c}$ & $0.95 \mathrm{~b}$ & $2.19 \mathrm{c}$ & $6.29 \mathrm{bc}$ \\
\hline 6.0 & $92.50 \mathrm{abc}$ & $0.73 \mathrm{c}$ & $2.11 \mathrm{~d}$ & $7.66 \mathrm{a}$ \\
\hline 7.0 & $97.50 \mathrm{a}$ & $0.84 \mathrm{bc}$ & $2.17 \mathrm{c}$ & $7.41 \mathrm{a}$ \\
\hline 8.0 & $95.00 \mathrm{ab}$ & $0.93 \mathrm{bc}$ & $2.19 \mathrm{c}$ & $7.00 \mathrm{ab}$ \\
\hline 9.0 & $87.50 \mathrm{bc}$ & $1.58 \mathrm{a}$ & $2.29 \mathrm{~b}$ & $5.62 \mathrm{c}$ \\
\hline 10.0 & $75.00 \mathrm{~d}$ & $1.66 \mathrm{a}$ & $2.97 \mathrm{a}$ & $4.02 \mathrm{~d}$ \\
\hline LSD $(0.05)$ & 8.0230 & 0.2078 & 0.0375 & 0.7116 \\
\hline
\end{tabular}

Means followed by the same letter in a column did not differ significantly according to LSD test $(\mathrm{p}<0.05) . \mathrm{T}_{50}$ : Time needed for $50 \%$ germination; MGT: Mean germination time; GI: Germination index; LSD: Least significance difference.

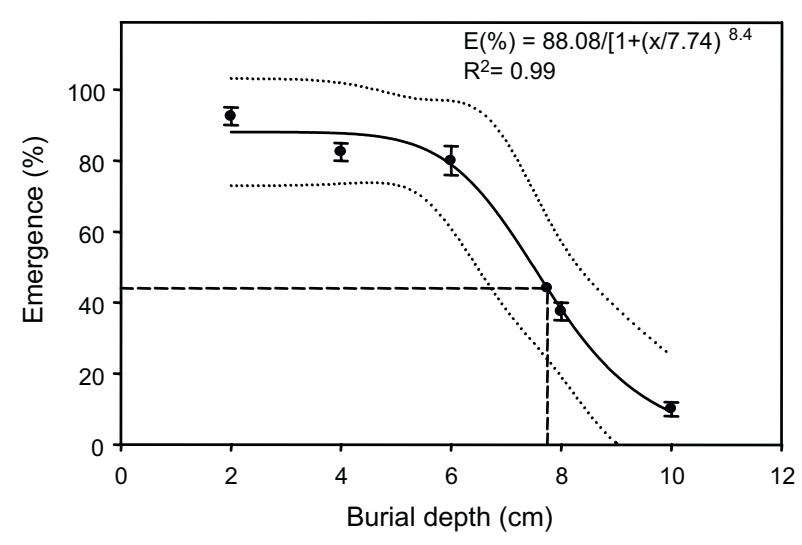

Figure 3 - Effect of planting depths on the emergence of $R$. capitata seedlings. Line represents the functional threeparameter logistic model $\left\{E(\%)=E_{\max } /\left[1+\left(x / x_{50}\right)^{E_{\text {rate }}}\right]\right\}$ fitted to the data.

$12 \mathrm{~cm}$ depth were dead. Little or no seedling emergence from these depths may be associated with seed energy reserves (Mennan \& Ngouajio, 2006). We used scarified seeds in our experiment to study seedling emergence at different depths. Seedling emergence might be expected to occur over an extended period, once the scarification processes require time in field conditions (Chauhan \& Johnson, 2008).

Sharp decrease in seedling emergence due to increased planting depth has been observed in annual sow thistle (Sonchus oleraceus) by Chauhan et al. (2006). Seedling 
emergence of seeds placed on the soil surface suggests that no till farming practices, in which a large proportion of the seed bank remains on the soil surface after crop planting, will favour seedling establishment of $R$. capitata. Similarly, conventional tillage practices, with seeds being buried at $6 \mathrm{~cm}$ depth at the most, would also enhance seedling emergence under field conditions. Whereas, deep tillage operations, where seeds are buried deep in the soil (10 to $12 \mathrm{~cm}$ or even more), can restrict the emergence of such weed. Appropriate understanding of germination and emergence behaviour of $R$. capitata should help to develop strategies that will not only suppress the germination of this weed but also help predict ecological range and potential spreading to new areas.

The results of our experiment suggest that $R$. capitata was able to germinate over a broad range of temperatures $\left(20\right.$ to $\left.40{ }^{\circ} \mathrm{C}\right)$; however, germination was greatest at temperatures of 30 and $35^{\circ} \mathrm{C}$. Furthermore, $R$. capitata germinated under reasonable levels of water stress $(-0.8 \mathrm{MPa})$, salinity $(200 \mathrm{mM})$ and shows rapid germination under varying $\mathrm{pH}$ levels (5-10). Seedling emergence appears to be optimum from the soil surface and the species may therefore be well suited to establishment under no-till given moist warm conditions generally found in late spring and summer in southern Punjab, in Pakistan. Increased seed burial depth has decreased seedling emergence, thus, high soil-disturbance tillage systems will reduce seedling establishment of $R$. capitata. The high germination ability of $R$. capitata under a wide range of ecological factors suggests that this species is likely to be the one to cause more problems in a near future if not managed appropriately.

\section{ACKNOWLEDGEMENT}

The financial support of Higher Education Commission, Government of Pakistan under indigenous Ph.D. (5000 fellowship) programme is highly acknowledged. We appreciate the valuable suggestions of Dr. Bhagirath S. Chauhan (Weed scientist, IRRI), which contributed to improve the quality of this paper.

\section{LITERATURE CITED}

AFZAL, I. et al. Physiological enhancement for alleviation of salt stress in wheat. Pak. J. Bot., v. 38, n. 5, p. 1649-1659, 2006.

AlBuQuerque, F. M. C. D. E.; CARVALHO, N. M. D. E. Effect of type of environmental stress on the emergence of sunflower (Helianthus annuus L.), soyabean (Glycine max (L.) Merril) and maize (Zea mays L.) seeds with different levels of vigor. Seed Sci. Technol., v. 31, n. 2, p. 465-467, 2003.

ALI, H. H. et al. Methods to break seed dormancy of Rhynchosia capitata, a summer annual weed. Chil. J. Agric. Res., v. 71, n. 3, p. 483-487, 2011.

ASSOCIATION OF OFFICIAL SEED ANALYSIS - ASOA. Rules for testing seeds. J. Seed Technol., v. 12, n. 3 , p. $1-112,1990$

AZHAR, M. J.; TARIQ, Y. M. Report on water crises and crop production gaps in Punjab: identification, risk analysis and mitigation measures (Wheat perspectives: Improving resource management to sustain food security). Pak. J. Bot., v. 41, n. 5, p. 2209-2216, 2009.

BASKIN, C. C. et al. Germination ecology of seeds of the annual weeds Capsella bursa-pastoris and Descurainia sophia originating from high northern latitudes. Weed Res., v. 44, n. 1, p. $60-68,2004$.

BENECH-ARNOLD, R. L. et al. Environmental control of dormancy in weed seed banks in soil. Field Crops Res., v. 67, n. 2 , p. $105-122,2000$

BRKIÆ, S. et al. Pea yield and its quality depending on inoculation, nitrogen and molybdenum fertilization. Plant Soil Environ., v. 50, n. 1, p. 39-45, 2004.

CHACHALIS, D.; REDDY, K. N. Factors affecting Campsis radicans seed germination and seedling emergence. Weed Sci., v. 48, n. 2 , p. $212-216,2000$

CHAUHAN, B. S.; GILL, G.; PRESTON, C. Factors affecting seed germination of annual sowthistle (Sonchus oleraceus) in southern Australia. Weed Sci., v. 54, n. 5 , p. 854-860, 2006.

CHAUHAN, B. S.; JOHNSON, D. E. Seed germination and seedling emergence of giant sensitiveplant (Mimosa invisa). Weed Sci., v. 56, n. 2, p. 244-248, 2008.

CHAUHAN, B. S.; JOHNSON, D. E. Germination ecology of Spiny (Amaranthus spinosus) and Slender Amaranth (A. viridis): troublesome weeds of direct seeded rice.

Weed Sci., v. 57, n. 4, p. 379-385, 2009. 
CHAUHAN, B. S.; JOHNSON, D. E. Germination, emergence, and dormancy of Mimosa pudica, Weed Biol. Manag., v. 9, n. 1, p. 38-45, 2009a.

CHAUHAN, B. S.; JOHNSON, D. E. The role of seed ecology in improving weed management strategies in the tropics. Adv. Agron., v. 105, p. 221-262, 2010.

COOLBEAR, P.; FRANCIS, A.; GRIERSON, D. The effect of low temperature pre-sowing treatment on the germination performance and membrane integrity of artificially aged tomato seeds. J. Exper. Bot., v. 35, n. 11, p. 1609-1617, 1984.

COUSENS, R. D.; MOSS, S. R. A model of the effects of cultivation on the vertical distribution of weed seeds within the soil. Weed Res., v. 30, n. 1, p. 61-70, 1990.

DOGRA, K. S. et al. Comparison of understorey vegetation in exotic and indigenous tree plantations in Shivalik Hills of N. W. Indian Himalayas (Himachal Pradesh). J. Ecol. Nat. Environ., v. 1, n. 5, p. 130-136, 2009.

ELLIS, R. A.; ROBERTS, E. H. The quantification of aging and survival in orthodox seeds. Seed Sci. Technol., v. 9, n. 2, p. $373-409,1981$.

ILDIS: online [Internet]. International Legume Database and Information Service. [cited 2010 January11]. Available from: http://www.ildis.org/LegumeWeb, 2010.

JAHAN, B.; VAHIDY, A. A.; ALI, S. I. Chromosome numbers in some taxa of Fabaceae mostly native to Pakistan. Ann. Missouri Bot. Garden., v. 81, n. 4, p. 792-799, 1994.

KHAJEH-HOSSEINI, M.; POWELL, A. A.; BINGHAM, I. J. The interaction between salinity stress and seed vigour during germination of soybean seeds. Seed Sci. Technol., v. 31, n. 3 , p. $715-725,2003$

KHAN, N. U.; KHAN, S. U. Integrated weed management in upland cotton, Pak. J. Weed Sci. Res., v. 9, n. 3-4, p. 185-192, 2003.

KOLHE, S. S.; CHOUBEY, N. K.; TRIPATHI, R. S. Evaluation of phenoxyaprop-p-ethyl and lactofen in soybean. Indian J. Weed Sci., v. 30, n. 3/4, p. 216-217, 1998.

LEFEVRE, P. Influence du milieu et des conditions d'exploration sur le development des plantes adventices. Effect particulier du pH et l'etat calcique. Ann. Agron., v. 7, n. 3, p. 299-347, 1956.

LEON, R. G.; OWEN, M. D. K. Tillage systems and seed dormancy effects on common waterhemp (Amaranthus tuberculatus) seedling emergence. Weed Sci., v. 54, n. 6, p. 1037-1044, 2006.
MENNAN, H.; NGOUAJO, M. Seasonal cycles in germination and seedling emergence of summer and winter populations of catchweed bedstraw (Galium aparine) and wild mustard (Brassica kaber). Weed Sci., v. 54, n. 1, p. 114-120, 2006.

MICHEL, B. E. Evaluation of the Water Potentials of Solutions of Polyethylene Glycol 8000. Plant Physiol., v. 72, n. 1, p. 66-70, 1983.

MOHLER, C. L. Weed life history: identifying vulnerabilities In: LIEBMAN, M.; MOHLER, C. L.; STAVER, C. P. (Eds.) Ecological management of agricultural weeds. Cambridge: Cambridge University Press, 2001. p. 40-98.

NIAZ, A. et al. Boron status of soils as affected by different soil characteristics- $\mathrm{pH}, \mathrm{CaCO} 3$, organic matter and clay contents. Pak. J. Agric. Sci., v. 44, n. 3, p. 428-435, 2007.

RAMAN, R.; KRISHNAMOORTHY, R. Nodulation and yield of mungbean (Vigna radiate $\mathrm{L}$.) influenced by integrated weed management practices. Legume Res., v. 28, n. 2, p. 128-30, 2005.

REDDY, K. N.; SINGH, M. Germination and emergence of hairy beggarticks (Bidens pilosa). Weed Sci., v. 40, n. 2, p. 195-199, 1992.

REJILI, M. et al. Influence of temperature and salinity on the germination of Lotus creticus (L.) from the arid land of Tunisia. Afr. J. Ecol., v. 48, n. 2, p. 329-337, 2009.

REUSS, S. A.; BUHLER, D. D.; GUNSOLUS, J. L. Effects of soil depth and aggregate size on weed seed distribution and viability in a silt loam soil. App. Soil Ecol., v. 16, n. 3, p. 209-217, 2001.

SHARMA, N. K.; SHARMA, M. M.; SEN, D. N. Seed Perpetuation in Rhynchosia capitata DC. Biol. Plant., v. 20, n. 3, p. 225-228, 1978.

STEEL, R. G. D.; TORRIE, J. H.; DICKEY, D. A. Principles and procedures of statistics. A biometrical approach. 3.ed. Singapore: McGraw Hill Book, 1997. p. 172-177.

WILSON, D. R. et al. Models of growth and water use of field pea (Pisum sativum L.). In: HEBBLETHWAITE, P. D.; HEATH, M. C.; DAWKINS, T. C. K. (Ed.). The pea crop. London: Butterworths, 1985.

YADAV, V. K.; SINGH, S. P. Losses due to weeds and response to pendimethalin and fluchloralin in varieties of summer sown Vigna radiate. Ann. Plant Protect. Sci., v. 13, n. 2, p. 454-457, 2005. 